\title{
A Comparative Analysis of the Morphological Characteristics of Elite Karatekas, Judokas, Taekwondoists, Boxers and Wrestlers
}

\author{
Análisis Comparativo de las Características Morfológicas de Karatistas, \\ Judistas, Taekwondistas, Boxeadores y Luchadores de Elite
}

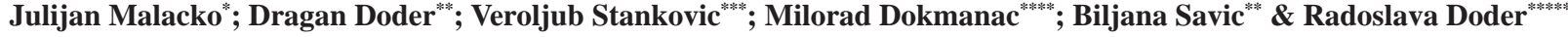

MALACKO, J.; DODER, D.; STANKOVIC, V.; DOKMANAC, M.; SAVIC, B. \& DODER, R. A Comparative analysis of the morphological characteristics of elite karatekas, judokas, taekwondoists, boxers and wrestlers. Int. J. Morphol., 33(1):245-250, 2015.

SUMMARY: The aim of this research was to use a system of 37 variables of morphological characteristics on a sample of 108 elite male athletes ( 25 karatekas, 27 judokas, 19 taekwondoists, 18 boxers and 19 wrestlers), aged 17 to 23 , to determine any statistically significant differences between the groups of athletes in terms of variable means, so that during the training process, the selection of athletes could be carried out in a proper and objective manner and that the training transformation processes could be managed more effectively. After processing the data using the statistical method of a multivariate and univariate analysis of variance (MANOVA/ ANOVA), we obtained results that indicate that among the karatekas, judokas, taekwondoists, boxers and wrestlers in the entire system of (multivariate) morphological variables there is a statistically significant difference between the means ( $\mathrm{p}=0.000)$. The results of the research have shown that what we are dealing with are different morphological structures of athletes involved in different sports. Since in the longitudinal and transversal dimensionality of the skeleton the values are more pronounced for boxers, wrestlers and karatekas, during selection it is necessary to be vigilant, since these are morphological characteristics which are genetically limited and can only change up to only $2 \%$ during the training process, while for voluminosity and body mass and subcutaneous fatty tissue there is the possibility of carrying out transformations of $20-50 \%$.

KEY WORDS: Males; Combat sports; Morphology; Comparison.

\section{INTRODUCCIÓN}

In sports science and training technology, it is believed that the study of the status of athletes on the basis of a comparative analysis of the morphological characteristics of athletes involved in different sports could be very useful, on the one hand for the aspect of selecting young athletes (Ifrim, 1984; Schwartz, 1984), and on the other hand, their transformation (Wolansky, 1984), since it is known that morphological characteristics are primarily under the influence of genetic components (endogenic factors) and environmental components (exogenic factors), wherein special attention should be paid to the fact that genetic influence is not the same for all of the latent morphological dimensions (Nikitjuk, 1988). Genetic potential in sport is usually manifested by means of a heritability coefficient, which represents the extent of the variance of each anthropological characteristic which is under the influence of genetic components, that is, the part of the variance which cannot be altered. For that purpose we usually use Holtzinger's ratio - the heritability coefficient (H2), although there is an entire list of other authors who achieved similar research results (Gaisl, 1981).

Research carried out to date in the field of genetics in sport indicates that top results can only be achieved through the application of modern training technology, and that they also depend on the genetic condition of certain anthropological skills, abilities and characteristics, where genetics gains a special place in the field of sport anthropology. In the space of morphological characteristics, the heritability coefficient, based on Holtziger's ratio, has a

* University of Novi Sad, Faculty of Sport and Physical Education, Novi Sad, Serbia.

** Provincial Institute for Sport and Sport Medicine, Novi Sad, Serbia.

*** University of Pris `tina, Faculty of Sport and Physical Education in Leposavic, Leposavic, Serbia.

***** Provincial Secretariat for Sports and Youth, Novi Sad, Serbia.

******University of Novi Sad, Faculty of Medicine, Novi Sad, Serbia. 
value of approximately $0.98(\mathrm{H} 2=0.98)$ for the dimensionality of the skeleton, body voluminosity $0.80-0.90$ $(\mathrm{H} 2=0.80-0.90)$, and fatty tissue $0.50(\mathrm{H} 2=0.50)$. Accordingly, the greatest transformation under the influence of exogenic factors (the process of sports training and the diet) is only possible in the case of fatty tissue, then body mass and body voluminosity, and can almost be disregarded in the case of the dimensionality of the skeleton. Research into the structure of skeletal muscles has indicated that the structure of motor units is under the strong influence of genetic factors (Wolansky, 1986; Moskatova 1986; Malacko, 1995).

The relationship between genetic and nongenetic potential can be interpreted as the interaction between the genetic and nongenetic part of the variance of every individual human feature, ability or characteristic, and related to that, the general rule applies that the greater the genotype part of the variance of a characteristic, the smaller its influence on that anthropological characteristic, and vice versa, the smaller the genotype variance, the greater the influence. The problem of determining the relative part of genotype variance in the overall variability of the anthropological characteristics to this very day has not become unified, since the heritability coefficients of certain anthropological characteristics determined by other authors and in other countries differ amongst themselves (Wolansky, 1971; Mrakovic', 1992; Malacko, 2009).

In modern practice, training technology and sports science, it is quite certain that in discovering numerous relevant and dominant factors for achieving top sports results, in addition to the contribution of genetic (limiting), what is also extremely significant is the formation of the nongenetic (transformational) potentials of athletes. This can be explained by the fact that seen from an anthropological point of view, there are no two identical subjects, since each subject is an individual unto himself, so that during the training process it is necessary to focus one's attention, not only on what is specific for the condition of the athlete and which occurred as the consequence of the training transformation process, but also on what is genetically characteristic for each individual as a part of the limiting state and it is almost impossible to alter it under the influence of training content (Stankovic' at al., 2009; Malacko \& Rado, 2004; Malacko \& Doder, 2008).

On the other hand, it is well known that even among sports there are almost no related motion structures, since each sport or sports discipline on its own represents a separate model situational-motor structure. Specifically speaking, in this research we are dealing with five different sports (karate, judo, taekwondo, boxing and wrestling), which at first glance make up a related group of sports, in the sports public known as combat sports. However, in the world sports public it is well known that they differ amongst themselves, both in an organizational structural (there are world, European, regional and national associations), and a competitive sense (sports rules and propositions, the manifestation of quality values and so on).

The aim of this research is to carry out a comparative analysis of the morphological characteristics of top karatekas, judokas, taekwondoists, boxers and wrestlers, on the basis of determined statistically significant differences in the means of certain morphological values, so that during the training process we could correctly and objectively select athletes and to manage the transformation training processes effectively - the modeling of sports activity, the diagnostics of athletes, the planning and programming of training sessions, operationalization, the control of the transformational process, the determination of the achieved effects (results) etc.

\section{MATERIAL AND METHOD}

The sample consisted of 108 males, aged 17 to 23, and was extracted from a population of athletes who had participated in combat sport in sports clubs on the territory of Vojvodina (25 karatekas, 27 judokas, 19 taekwondoists, 18 boxers and 19 wrestlers).

The sample consisted of a total of 37 morphological variables (10 variables of the longitudinal dimensionality of the skeleton, 8 variables of the transversal dimensionality of the skeleton, 11 variables of voluminosity and body mass and 8 variables of subcutaneous fatty tissue). The variables were measured using the method developed by the International Biological Program (IBP).

In order to determine the differences in the arithmetic means of the applied variables between the karatekas, judokas, taekwondoists, boxers and wrestlers, the statistical method of the multivariate and univariate analysis of variance (MANOVA/ANOVA) was used. The multivariate testing of the null-hypothesis was that the group centroids were equal to the common centroid (General MANOVA) was carried out using Wilks' Lambda (1) and the F-test (F), and then their statistical significance was determined (p). The univariate statistical significance of the differences ( $p$ ) between the arithmetic means of the groups based on the variables was also calculated using the F test. The data were processed using the IBM SPSS Statistics 19 program. 


\section{RESULTS}

From the calculated statistical values shown in Table I, we can clearly see that among the karatekas, judokas, taekwondoists, boxers and wrestlers in the entire system of the (multivariately) applied 37 morphological variables there is a statistically significant difference between their means $(\mathrm{p}=0.000)$.
By analyzing Table I and Figure 1, where the univariate values of the means are shown in the variables of longitudinal dimensionality of the skeleton, it can clearly be seen that the boxers (shown in the Table I as 1) have the greatest values, followed by the karatekas, (2), wrestlers (3), taekwondoists (4) and judokas (5). In the variables of trans-

Table I. The multivariate and univariate statistically significant differences in the means of morphological characteristics.

\begin{tabular}{|c|c|c|c|c|c|c|c|}
\hline Variables & Mk & $\mathbf{M j}$ & Mt & Mb & Mw & $\mathbf{F}$ & $\mathbf{p}$ \\
\hline \multicolumn{8}{|c|}{ Longitudinal dimen sionality of the skeleton } \\
\hline BOHEI - body height & 176.582 & $169.35^{5}$ & $172.78^{4}$ & $180.85^{1}$ & 173.923 & 5.22 & $0.001 *$ \\
\hline ARMSP - arm span & 179.322 & $169.25^{5}$ & 172.943 & $183.05^{1}$ & 171.124 & 3.36 & $0.013^{*}$ \\
\hline RIGLL - right leg length & $100.10^{2}$ & 94.465 & $97.62^{3}$ & $102.24^{1}$ & $96.31^{4}$ & 6.82 & $0.000 *$ \\
\hline LEFLL - left leg length & 100.242 & 94.335 & $97.54^{3}$ & $102.32^{1}$ & $97.47^{4}$ & 7.43 & $0.000 *$ \\
\hline RIARL - right arm length & 77.452 & 74.445 & $74.59^{4}$ & $78.78^{1}$ & $76.52^{3}$ & 4.13 & $0.004 *$ \\
\hline LEARL - left arm length & 77.272 & 74.345 & $74.44^{4}$ & 78.731 & $76.57^{3}$ & 4.05 & $0.004 *$ \\
\hline RIHAL - right hand length & 19.464 & 18.915 & $19.70^{2}$ & 20.871 & $19.57^{3}$ & 4.03 & $0.004 *$ \\
\hline LEHAL - left hand length & 19.304 & 18.835 & $19.35^{3}$ & 21.111 & $19.62^{2}$ & 6.20 & $0.000 *$ \\
\hline RIFOL - right foot length & 26.122 & 24.984 & $24.91^{5}$ & 26.181 & $25.55^{3}$ & 2.91 & $0.025 *$ \\
\hline $\begin{array}{l}\text { LEFOL - left foot length } \\
\text { Transversal dimensionality of the ske }\end{array}$ & 26.171 & 25.005 & $25.18^{4}$ & $26.15^{2}$ & $25.55^{3}$ & 2.48 & $0.048 *$ \\
\hline SHOWI - shoulder width & 40.303 & 38.094 & $37.92^{5}$ & $41.18^{2}$ & $41.25^{1}$ & 6.76 & $0.000 *$ \\
\hline PELWI - pelvic width & 27.414 & 28.142 & $27.23^{5}$ & $28.18^{1}$ & $27.63^{3}$ & 0.65 & 0.626 \\
\hline RIHWI - right hand width & $8.50^{3}$ & 8.154 & $7.84^{5}$ & 8.901 & $8.86^{2}$ & 13.63 & $0.000 *$ \\
\hline LEHWI - left hand width & $8.34^{3}$ & 8.024 & $7.77^{5}$ & 8.801 & $8.74^{2}$ & 14.01 & $0.000 *$ \\
\hline RIHSP - right hand span & 21.504 & 20.455 & $21.66^{3}$ & 22.011 & $21.67^{2}$ & 1.34 & 0.257 \\
\hline LEHSP - left hand span & 21.534 & 20.525 & $21.57^{3}$ & 21.851 & $21.67^{2}$ & 1.08 & 0.366 \\
\hline RIWDI - right wrist diameter & $5.67^{3}$ & 5.445 & $5.49^{4}$ & 6.072 & $6.07^{1}$ & 7.47 & $0.000 *$ \\
\hline \multicolumn{8}{|l|}{ Voluminosity and body mass } \\
\hline UAVE - right upper arm volume - ext. & 31.283 & 29.734 & $27.32^{5}$ & 33.231 & $32.78^{2}$ & 10.19 & $0.000 *$ \\
\hline UAVE - left upper arm volume - ext. & 31.243 & 29.584 & $27.07^{5}$ & $33.08_{1}$ & $32.60^{2}$ & 10.71 & $0.000 *$ \\
\hline UAVF - right upper arm volume flex. & 33.693 & 31.714 & $29.54^{5}$ & 36.331 & $35.93^{2}$ & 12.25 & $0.000 *$ \\
\hline UAVF - left upper arm volume flex. & 33.523 & 31.544 & $29.15^{5}$ & 36.211 & $35.52^{2}$ & 12.73 & $0.000 *$ \\
\hline ILAV - right lower arm volume & 27.373 & $25.99_{4}$ & $24.77^{5}$ & 30.051 & $28.74^{2}$ & 16.00 & $0.000 *$ \\
\hline ILAV - left lower arm volume & 26.813 & 25.874 & $24.50^{5}$ & $29.70_{1}$ & $28.56^{2}$ & 15.09 & $0.000 *$ \\
\hline ILLV - right lower leg volume & 37.962 & 36.494 & $35.77^{5}$ & 38.431 & $37.85^{3}$ & 1.62 & 0.173 \\
\hline ELLV - left lower leg volume & 39.021 & 36.434 & $35.66^{5}$ & 38.232 & $37.05^{3}$ & 2.14 & $0.081 *$ \\
\hline EULV - left upper leg volume & $63.80^{1}$ & 55.214 & $52.76^{5}$ & 57.922 & $57.74^{3}$ & 4.17 & $0.004 *$ \\
\hline BVOL - abdominal volume & $76.16^{4}$ & 79.023 & $75.94^{5}$ & 83.472 & $83.57^{1}$ & 2.46 & $0.049 *$ \\
\hline OMAS - body mass & 74.833 & 66.254 & $63.68^{5}$ & $79.66_{1}$ & $79.56^{2}$ & 5.47 & $0.000 *$ \\
\hline \multicolumn{8}{|l|}{ S ubcutaneous fatty tissue } \\
\hline AXSKI - axillary skinfold & $8.27^{4}$ & 7.943 & $7.78^{2}$ & 6.471 & $9.19^{5}$ & 1.61 & 0.177 \\
\hline BISKI - biceps skinfold & $5.30^{4}$ & 5.123 & $6.76^{5}$ & 4.411 & $4.48^{2}$ & 5.40 & $0.001 *$ \\
\hline BASKI - back skinfold & 11.034 & 10.483 & $10.04^{2}$ & 9.981 & $13.71^{5}$ & 2.10 & 0.086 \\
\hline UPASK - upper arm skinfold & 11.723 & 11.984 & $12.30^{5}$ & 7.721 & $9.13^{2}$ & 3.59 & $0.009 *$ \\
\hline UPL SK - upper leg skinfold & 16.213 & 17.114 & $17.27^{5}$ & $11.18^{1}$ & $13.64^{2}$ & 2.56 & $0.043 *$ \\
\hline LOLSK - lower leg skinfold & $10.26^{3}$ & 12.675 & $11.27^{4}$ & 5.751 & $7.60^{2}$ & 6.77 & $0.000 *$ \\
\hline SUSKI - suprailiac skinfold & $9.71^{4}$ & 10.635 & $9.30^{2}$ & $8.10^{1}$ & $9.59^{3}$ & 0.65 & 0.628 \\
\hline ABSKI - abdominal skinfold & 14.775 & 13.294 & $12.43^{2}$ & 9.361 & $12.51^{3}$ & 1.58 & 0.183 \\
\hline
\end{tabular}

$\mathrm{l}=0.020 ; \mathrm{F}=3.047 ; \mathrm{p}=0.000 * \mathrm{Mk}=$ karatekas $(25) ; \mathrm{Mj}=$ judokas $(27) ; \mathrm{Mt}=$ taekwondoists $(19) ; \mathrm{Mb}=$ boxers $(18) ; \mathrm{Mr}=$ wrestlers $(19), 1,2,3,4,5-$ order in terms of values. $1=$ Wilks' Lambda; F= F-ratio; $\mathrm{p}=$ the statistical significance of the differences between arithmetic means at the $\mathrm{p} \leq 0.000$ level. 


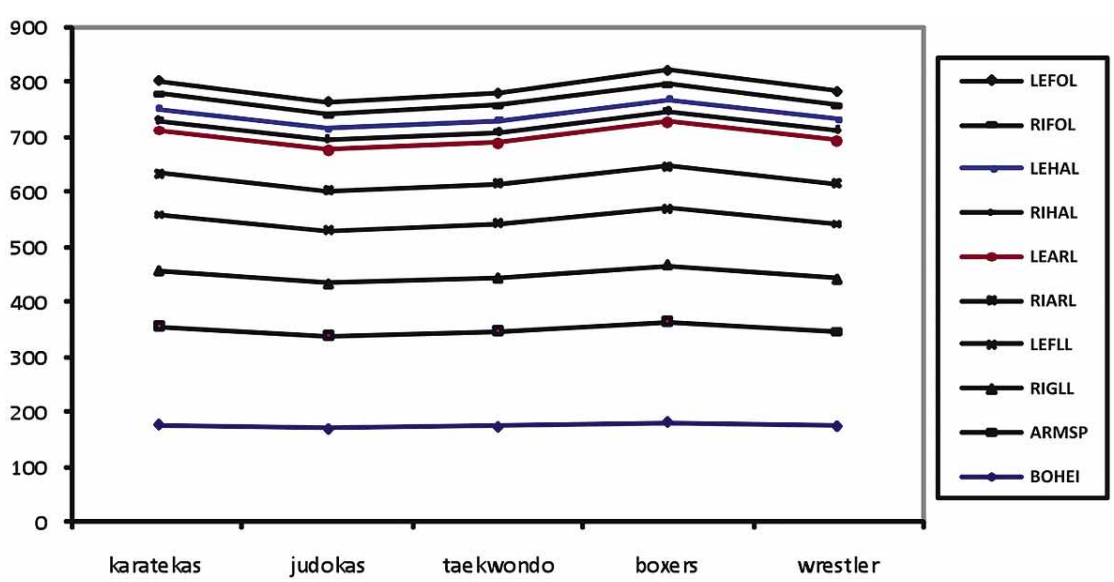

Fig. 1. Longitudinal dimensionality of the skeleton.

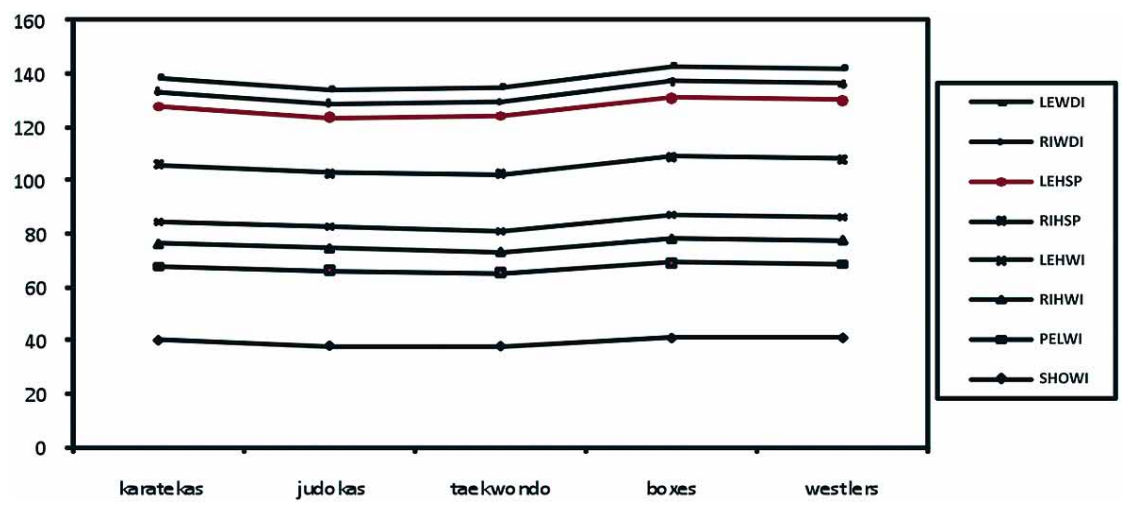

Fig. 2. Trasnversal dimensionality of the skeleton.

versal dimensionality of the skeleton, boxers (1) also have the highest values, then the wrestlers, (2), karatekas (3), judokas (4) and taekwondoists (5).

Unlike the longitudinal and transversal dimensionality of the skeleton, in the variables for the means and body voluminosity, the greatest values are found for the boxers (1), then the wrestlers (2), karatekas (3), judokas (4) and taekwondoists (5). In the variables of subcutaneous fatty tissue, the boxers (1) have the greatest (that is smallest) values, followed by wrestlers (2), taekwondoists (3), karatekas (4) and judokas (5).

\section{DISCUSSION}

The results have shown that the boxers, wrestlers and karatekas have the greatest values for the hard tissues - the longitudinal and transversal dimensionality of the skeleton (Figs. 1 and 2).
This indicates that already during the initial selection in these sports, attention should be paid to the genetic limitations of morphological build and longitudinal and transversal dimensionality of the skeleton. In addition, among the karatekas, judokas and taekwondoists, unlike the boxers and wrestlers, an expected decrease in the values of mass and body voluminosity and subcutaneous fatty tissue was determined, considering that these sports require a more harmonious morphological makeup and interactional manifestations with motor (speed-coordination) and functional (anaerobic) abilities.

Unlike the boxers who predominantly have hard tissues, which are manifested in the sum of the longitudinal and transversal dimensionality in the single skeletal dimensionality, the wrestlers exhibit increased values in the soft tissues, defined through the amount of muscle mass. The smallest values for subcutaneous fatty tissue were found among the boxers and wrestlers (Figs. 3 and 4).

This indicates that already during initial selection it is important to pay attention to the morphological build of the dimensionality of the skeleton, and that based on these genetically limited morphological characteristics, during the training process, greater attention is awarded to the most optimal transformation of soft tissue, where attention needs to be paid to the fact that the voluminosity of the body at the same time means an increase in the amount of muscle mass which affects general motor and functional (aerobic-anaerobic) effectiveness, while athletes who have a greater amount of subcutaneous fatty tissue (a disruptive factor) have problems with motor manifestations of any type (Malicevic, 2007; Hraski \& Hraski, 2010). 


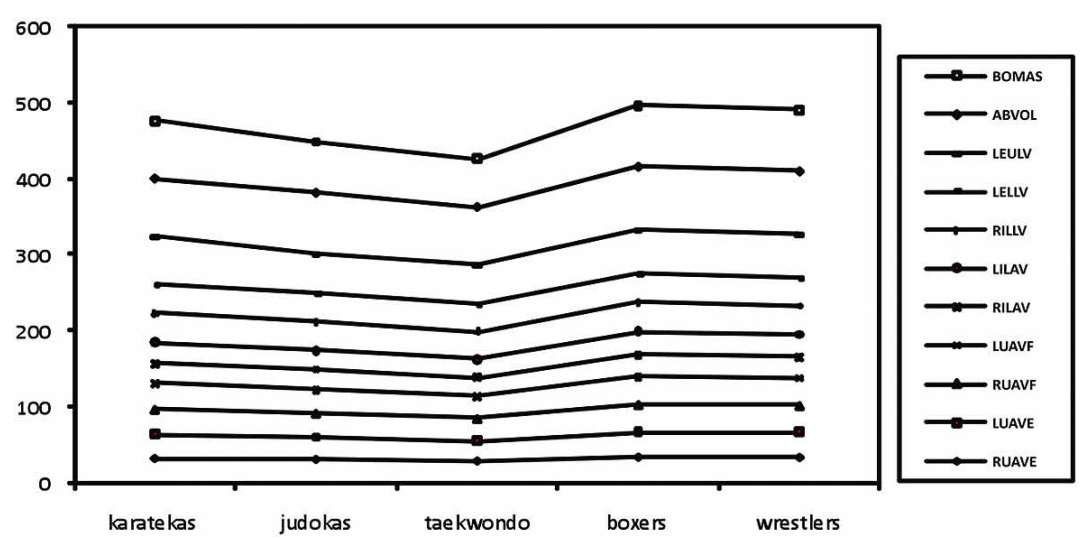

Fig. 3. Voluminosity and body mass.

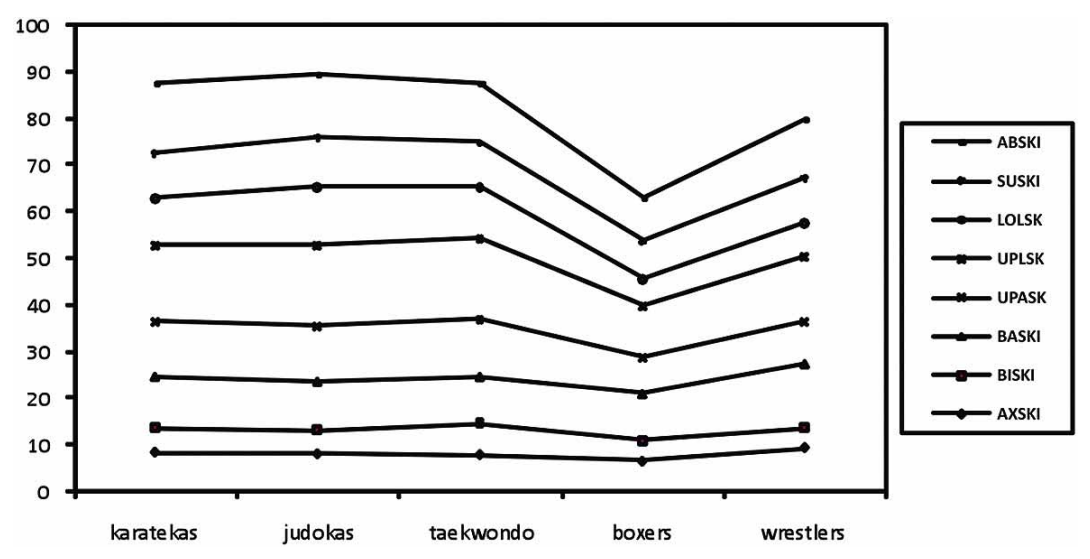

Fig. 4. Subcutaneous fatty tissue.

In sports theory and practice it is known (Ostojic, 2005) that muscle volume has a direct influence on the ability to develop strength, and thus to define the possibility of greater or less effective movement, overcoming resistance or obstacles, and that subcutaneous fatty tissue in the motor manifestations of athletes represents a 'disruptive factor' (Sinobad, 2005; Rogulj et al., 2012; Ostojic, 2002; Katic et al., 2005). At the same time it is important not to disregard the need for an optimal amount of fatty tissue as well, considering that it contains fatty acids which are necessary for the human body as they enable different chemical processes, but also allow the body to build certain kinds of tissue and produce energy.

During the optimal transformation of soft tissue (the increase in muscle mass and the reduction of subcutaneous fatty tissue) we must strictly adhere to the balance and allow active muscle mass to develop continually through the muscle fibers and the appropriate diet, considering that great muscle mass also uses up great amounts of energy (Cook et al., 2004). Therefore we need to bear in mind that fatty acids, as an integral part of fatty tissue, can be used only during low intensity work, since they can only be 'burned' under aerobic conditions of training load, provided that work takes place long enough and continuously. What this means is that during the training process, we must optimally enable the muscle system to work, which will increase the overall motor effectiveness and efficiency.

A comparative analysis of the morphological characteristics of elite karatekas, judokas, taekwondoists, boxers and wrestlers on the basis of the determined statistically significant differences in the means among the 37 morphological values determined that in the entire system of (multivariately) applied variables there is a statistically significant difference between the means at the $\mathrm{p}=0.000$ level. Univariate procedures were also used to determine that boxers, wrestlers and karatekas have the greatest values for hard tissues longitudinal and transversal dimensionality of the skeleton, while in the case of the karatekas, judokas and taekwondoists, unlike the boxers and wrestlers, we obtained the expected decrease in the values of mass and body voluminosity and subcutaneous fatty tissue, considering that these sports require a more harmonious morphological makeup and interactional manifestations with motor (speed, coordination, agility) and functional (anaerobic) skills. The smallest values determined for subcutaneous fatty tissue were determined for the boxers and wrestlers. This indicates that during initial selection, depending on the combat sport, it is necessary to pay attention to the morphological structure of longitudinal and transversal dimensionality of the skeleton, and that in accordance with these genetically limited morphological characteristics, during the training process, more attention is needed for the more optimal transformation of the soft tissue, while athletes who have greater amounts of subcutaneous fatty tissue (a disruptive factor) have problems which motor manifestations of any type, and thus should be in harmony with the more optimal norms, needs and possible consequences. 
MALACKO, J.; DODER, D.; STANKOVIC, V.; DOKMANAC, M.; SAVIC, B. \& DODER, R. Análisis comparativo de las características morfológicas de karatistas, judistas, taekwondistas, boxeadores y luchadores de élite. Int. J. Morphol., 33(1):245-250, 2015.

RESUMEN: El objetivo de esta investigación consistió en utilizar un sistema de 37 variables de las características morfológicas de una muestra de 108 deportistas de élite masculinos (25 karatekas, 27 judokas, 19 taekwondistas, 18 boxeadores y luchadores 19), de 17 a 23 años, para determinar alguna diferencia que sea estadísticamente significativa entre los grupos de atletas en términos de medios de variables, de modo que durante el proceso de formación, la selección de los atletas podría llevarse a cabo de una manera adecuada y objetiva, y que los procesos de transformación de la formación podrían ser manejados de manera más eficaz. Después de procesar los datos mediante el método estadístico de análisis multivariado y univariado de la varianza (MANOVA/ANOVA), se obtuvieron resultados que indican que entre los karatekas, judokas, taekwondistas, boxeadores y luchadores en todo el sistema de (multivariable) variables morfológicas no existe una diferencia estadísticamente significativa entre las medias $(\mathrm{p}=0,000)$. Los resultados de la investigación han demostrado que se observan diferentes estructuras morfológicas de los atletas que participan en diferentes deportes. Dado que en la dimensionalidad longitudinal y transversal del esqueleto y sus valores son más pronunciados para los boxeadores, luchadores y karatekas. Durante la selección es importante estar atentos, ya que estas son las características morfológicas que genéticamente son limitantes y solamente se pueden cambiar hasta el $2 \%$ durante el proceso de formación, mientras que para la voluminosidad y la masa corporal y el tejido graso subcutáneo es posible efectuar transformaciones del 20-50\%.

PALABRAS CLAVE: Hombres; Artes marciales; Morfológico; Comparación.

\section{REFERENCES}

Cook, J. L.; Kiss, Z. S.; Khan, K. M.; Purdam, C. R. \& Webster, K. E. Anthropometry, physical performance, and ultrasound patellar tendon abnormality in elite junior basketball players: a cross-sectional study. Br. J. Sports Med., 38(2):206-9, 2004.

Gaisl, G. Genetic components of sport talents. Mod. Train., 3, 1981.

Hraski, M. \& Hraski, Z. Basic anthropometric characteristics of female alpine skiers in period 2006-2010. Croat. Sports Med. J., 25:81-6, 2010.

Ifrim, M. The genetic and anthropological method in sport selection. Genetics of psychomotor trains in man. Warshawa, Polish Academy of Sciences, 1984. pp. 53-64.

Katic, R.; Blazevic, S.; Krstulovic, S. \& Mulic, R. Morphological structures of elite Karateka and their impact on technical and fighting efficiency. Coll. Antropol., 29(1):79-84, 2005.

Malacko, J. Anthropological genetics in the function of sport humanization. [In Serbian]. Godis`njak Akademije pravnih znanosti Hrvatske, 7:5660, 1995.

Malacko, J. \& Rado, I. Technology of sport and sport training. [In Bosnian]. Sarajevo, University of Sarajevo, Faculty of Sport and Physical Education, 2004. pp.158-221.

Malacko, J. \& Doder, D. Technology of sport training and recovery. [In Serbian]. Novi Sad, Provincial Institute for Sport and Sport Medicine, 2008 .

Malacko, J. Interaction between genetic and non genetic potentials in the function of creation and development of sportsmen individuality. Sport Sci., 2(2):36-40, 2009.

Malicevic, S. Comparative analysis anthropomorphological and cardiovascular parameters seniors and cadets of elite athletes. Sport. Med., 7(3):27-80, 2007.

Moskatova, A. K. Genetic condition of functional capacity of young sportsmen. Kineziologija, 6(1):13-5, 1986.

Mrakovic', M. Defining the limitation factor. [In Croatian]. Zagreb, University of Zagreb, Faculty of Physical Culture, 1992. pp.84-93.
Nikitjuk, B. A. Adaptation, constitution and motorics. Kineziologija, 20(1):16, 1988.

Ostojic, S. M. Changes in body fat content of top-level soccer players. $J$. Sports Sci. Med., 1(2):54-5, 2002.

Ostojic, S. M. Current trends body composition analysis of athletes. Sport. Med., 5(1):1-11, 2005.

Rogulj, N.; Srhoj, L. \& Cavala, M. Differences in anthropologic characteristics between kinesiologically active and inactive female students. Coll. Antropol., 36(3):945-50, 2012.

Schwartz, V. Genetics and selection in sport. Genetics of psychomotor trains in man. Warshawa, Polish Academy of Sciences, International Society of Sport Genetics and Somatology, 1984. pp.105-9.

Sinobad, M. Comparison of anthropometric characteristics and body composition among school children and players of the same age. Sport. Med., 5(2):43-52, 2005

Stankovic, V.; Malacko, J. \& Doder, D. The differences in morphological characteristics among top handball, basketball and football players. Acta Kinesiol., 3(2):90-94, 2009.

Wolansky, N. Genetic and anthropological factors of sport achievement of motor development. [In Serbian]. Modern training, 4, 1971.

Wolansky, N. Genetics, and training possibility of psychomotor trains in man. Genetics of psychomotor trains in man. Warshawa, Polish academy of sciences, International Society of Sport Genetics and Somatology, 1984. pp.21-52.

Wolansky, N. Endurance fitness and persistence fitness. Genetic control and training possibilities. Kineziologija, 6(1):21-32, 1986

\section{Correspondence to: \\ Dragan Doder}

Senior Research Associate

Provincial Institute for Sport and Sport Medicine

Masarikova 25, 21000

Novi Sad - SERBIA

Received: 20-01-2014

Accepted: 06-12-2014 